\title{
The species of Scarabaeus Linnaeus (Coleoptera: Scarabaeidae) in Bulgaria and adjacent regions: faunal review and potential distribution
}

\author{
Jorge M. Lobo, Borislav V. Guéorguiev \& Evgeni I. Chehlarov
}

Lobo, J. M., Guéorguiev, B. V. \& Chehlarov, E. I. 2010: The species of Scarabaeus Linnaeus (Coleoptera: Scarabaeidae) in Bulgaria and adjacent regions: faunal review and potential distribution. - Entomol. Fennica 21: 202-220.

We compile the available georeferenced information on Bulgarian Scarabaeus species, including both bibliographic and natural history data to provide basic ecological and biogeographical information as well as maps of climatically favourable areas (potential distributions) for each one of the species. Scarabaeus species in Bulgaria seem to be generally distributed across low altitude areas mainly under warm temperate or Mediterranean conditions, although $S$. variolosus appears to be the species adapted to the warmest conditions and $S$. armeniacus inhabits areas of medium altitude. Our results indicate that it is necessary to carry out an extra survey effort in the northern lowlands, away the Stara Planina Mts. in order to validate current climatically suitable territories for some species. However, the recent land use transformations of these lowland areas, together with the general decline of roller dung beetle populations, suggest that this validation may not be possible.

J. M. Lobo, Departamento de Biodiversidad y Biología Evolutiva, Museo Nacional de Ciencias Naturales, C.S.I.C., Madrid, Spain; E-mail: monj117 (a)mncn.csic.es

B. V. Guéorguiev, National Museum of Natural History, BAS, Blvd. Tzar Osvoboditel 1, 1000, Sofia, Bulgaria; E-mail: bobivg@yahoo.com

E. I. Chehlarov, Institute of Zoology, BAS, Blvd. Tzar Osvoboditel 1, 1000 Sofia, Bulgaria; E-mail: evgeni.chehlarov@gmail.com

Received 2 April 2009, accepted 15 March 2010

\section{Introduction}

The family Scarabaeidae contains many species highly specialized in the consumption of herbivorous faeces (Halffter \& Edmonds 1982). Although there is no agreement on the phylogenetic relationships within this family (see Halffter \& Edmonds 1982, Zunino 1984, 1985, Cambefort 1991, Montreuil 1998, Browne \& Scholtz 1995, 1998, 1999), it has been subdivided classically into two subfamilies (Scarabaeinae and Coprinae, sensu Balthasar 1963) according to behavioural and morphological criteria. While Coprinae species bury the dung in the soil beneath the dung pats for nidification or feeding purposes (tunnelers), Scarabaeinae species construct more or less spherical pieces of dung and roll them several meters away from the dung source before burying them (rollers). Recent molecular (Villalba et al. 2002) and morphological data 


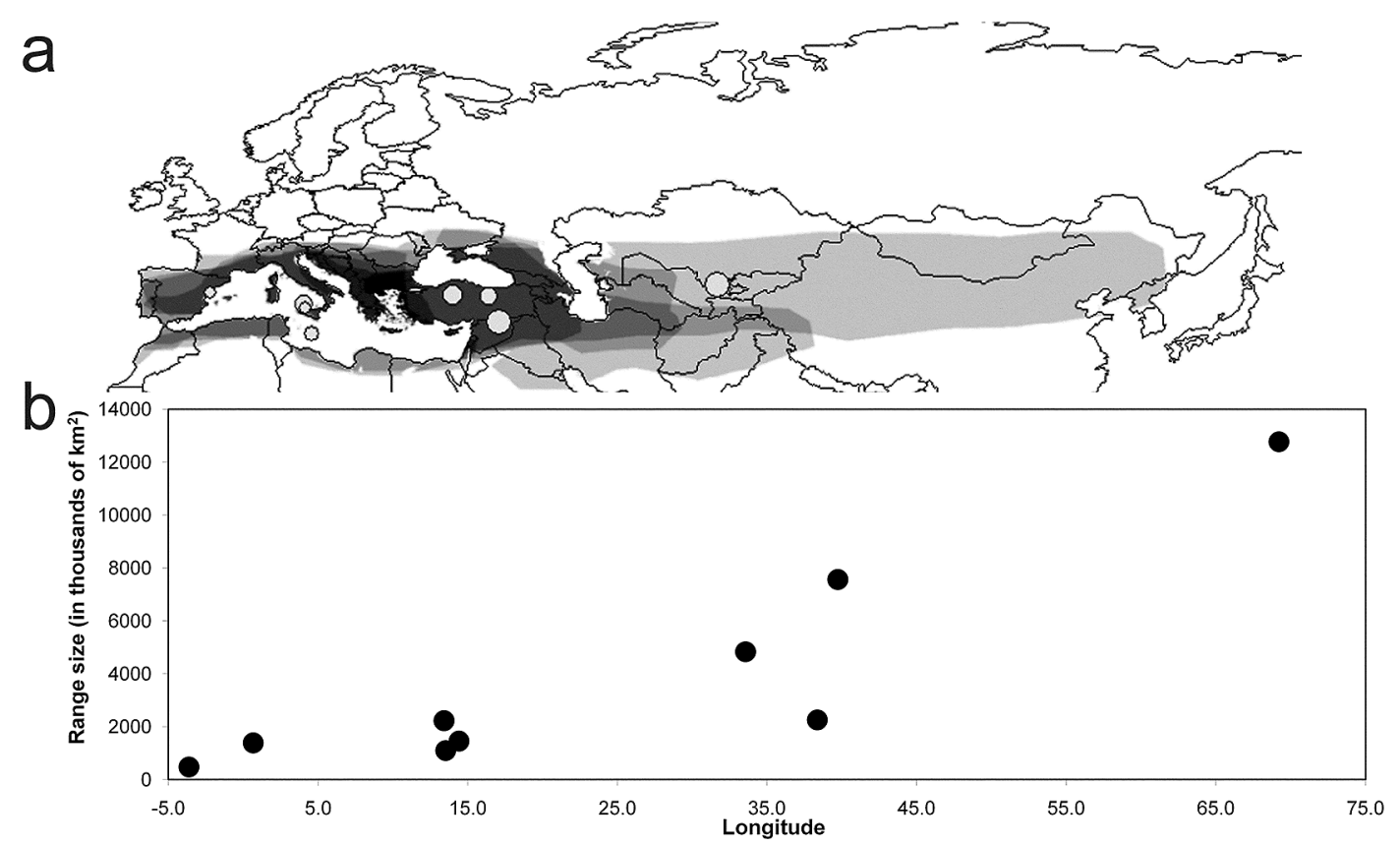

Fig. 1. - a. Geographic variation in the number of Scarabaeus species present in Europe. The circles represent the central distribution of each one of the nine species. The size of each circle is proportional to the total rangesize. - b. Relationship between the central longitude of each species and its range size. Note that the species with narrow distributions are those occupying south-western Europe and north-western Africa.

(Philips et al. 2002, 2004, Forgie et al. 2005, 2006) suggest that this classical division lacks phylogenetic sense, because the rolling behaviour probably originated independently several times along the evolutionary history of Scarabaeinae dung beetles.

Of the six recognized tribes of Scarabaeinae, the Scarabaeini contain 11 genera according to Hanski \& Cambefort (1991), which are mainly distributed in arid regions of the Afrotropical and Palaearctic regions (Davis et al. 2002). Within this tribe, Scarabaeus Linnaeus, 1758 is the most speciose genus (142 species; see Schoolmeesters 2007) and is the only one present in the Palaearctic region (Löbl et al. 2006). Scarabaeus species are mainly distributed in the southern part of the Afrotropical region under drier climates, but also in warmer climatic areas of the Palaearctic region from the Western Mediterranean to central Asia (Zur Strassen 1967). Thirty one species of Scarabaeus inhabit the Palaearctic region $(22 \%$ of the world total) belonging to five subgenera: Scarabaeus, Ateuchetus, Pachysoma, Kheper and Mnematidium. In Europe it is possible to find only nine species belonging to the two first sub- genera (see Löbl et al. 2006), which rarely surpass the $48^{\circ} \mathrm{N}$ in latitude and generally are also present in the Asia Minor region or North Africa (see Fig. 1).

Scarabaeus species have very special behavioural and physiological adaptations (Byrne et al . 2003, Verdú et al. 2004) and have been used as indicators for conservation purposes (Mc Geoch et al. 2002, Davis et al. 2004). Being found in open biomes, these species seem to have suffered a considerable recent decline both in geographical area of occupancy and in population sizes since the last half of the $20^{\text {th }}$ century (Lobo 2001, see also Leclerc et al. 1980, Lumaret 1990, Lumaret \& Kirk 1991, Barbero et al. 1999, Lobo et al. 2001, Romero-Samper \& Lobo 2006, Carpaneto \& Mazziota 2007) probably due to a great reduction in traditional pastoral practices (Hutton \& Giller 2003, Barbero et al. 1999), urban development with the associated changes in land use (Lobo 2001, Lobo et al. 1997, 2001), the increase of chemical contamination (Hole et al. 2005) and/or the increase in predation by some bird species (Gittings et al. 1994, Gittings \& Giller 1999, Horgan \& Berrow 2004). 
Table 1. List of the studied references from which localities for Scarabaeus species were extracted.

Joakimov 1899

Markovich 1904

Nedelkov 1905

Markovich 1909

Nedelkov 1909

Netolitzky 1912

Stolfa 1938

Pittioni 1940

Drenski 1942

Csiki 1943
Mikšić 1953, 1955, 1957

Panin 1957

Karnoschitzky 1959

Mikšić 1959

Angelov 1960

Balthasar \& Hrubant 1960

Muche 1964

Angelov 1965

Dimitrova \& Trifonov 1965

Zacharieva 1965a, b, c

\author{
Dimitrova \& Genov 1966 \\ Trifonov 1966 \\ Dimitrova, \& Genov 1968 \\ Zaharieva-Stoilova 1974 \\ Zaharieva \& Dimova 1975 \\ Zaharieva et al. 1975 \\ Zaharieva-Stoilova \& Dimova 1980, 1981 \\ Král \& Malý 1993 \\ Bunalski 2000 \\ Guéorguiev 2001
}

The main aim of this study is to provide comprehensive information on the distribution of the five Scarabaeus species cited from Bulgaria and present in closest adjacent territories by revising the distributional data available both in bibliographic sources and in several natural history collections. We firstly examined the sources and the available information on the distribution of each species individually. We afterwards applied a procedure able to generate potential distributions (see Jiménez-Valverde et al. 2008) to estimate for each species the location of those climatically favourable areas in Bulgaria and its closest neighbouring regions, according to the available distributional data. Finally, we examined the intra-species variation in environmental conditions of these species as well as the temporal increase in the compiled information across decades.

\section{Material and methods}

The present research is based in a critical revision of all the available material from the collections of the Institute of Zoology, Sofia (Bulgaria), the National Museum of Natural History, Sofia (Bulgaria) and the private collection of Mr. E. Migliaccio (Rome, Italy). A total of 274 specimens have been studied; 178 of them have been recorded in the literature, and 96 are new records. The revised literature includes 40 papers (see Table 1) which include records of Scarabaeus species both in Bulgaria and in its neighbouring countries. Papers which repeat older data or contain inaccurate records are not considered. All except five sources (Netolitzky 1912, Mikšić 1955, Panin 1957, Karnoschitzky 1959, Balthasar \&
Hrubant 1960) contain data for Bulgaria. In the whole, faunistic information on Bulgarian Scarabaeus species has been published more or less regularly during the last 110 years. All locality data was georeferenced when no information was available in the original sources (see Appendix).

The data from seventeen environmental variables were extracted from the Worldclim 1.4 database (Hijmans et al. 2005) freely accessible at http://www.worldclim.org/. These variables are: mean altitude, precipitation, maximum, mean and minimum temperatures for each one of the four annual seasons and their values for each $5 \times 5 \mathrm{~km}$ cell calculated for the Bulgarian territory and bordering areas (from -39000 to 15500 in longitude, and from 4560000 to 4950000 in latitude; UTM $36 \mathrm{~N}$ reference system); an approximated area of $196,275 \mathrm{~km}^{2}$ (7851 UTM cells). Using this climatic and topographic information we firstly carried out exploratory analyses to identify the main environmental requirements for each species according to the available presence information. The recommended Ecological-Niche Factor Analysis (ENFA) was used for this purpose (see Hirzel et al. 2002, Basille et al. 2008, Calenge \& Basille 2008, Calenge et al. 2008) since it provides a means of identifying the response of the species to the main environmental variations in the study area. ENFA transforms the original ecogeographical variables into new orthogonal axes; the first one accounts for the marginality of the species (the differences between the conditions inhabited by the species and the regional average conditions) while subsequent axes account for the tolerance of the species in the study area (specialisation axes). ENFA was performed using the freely available software Biomapper 
Table 2. Median scores of some selected environmental variables for the localities in which each Scarabaeus species have been cited. The lower and upper quartiles are included in brackets. $\mathrm{N}$ is the number of cells of $0.083^{\circ}$ at which each species was recorded, A is altitude, AP is annual precipitation, JP is July precipitation, mTJ is minimum temperature of January, and MTJ is maximum temperature of July. KW are Kruskal-Wallis non-parametric test values for between species differences in each explanatory variable. Precipitation values are in $\mathrm{mm}$ while temperature ones are in ${ }^{\circ} \mathrm{C}$. The initials of the species name of each species (Sa, Sv, Sp, St and Ss) represent those species with statistically significant differences using post-hoc multiple comparison test of mean ranks to estimate which species are particularly different from each other with regard to each one of the climatic variables. *: $P \leq 0.05,{ }^{* *}: P \leq 0.01,{ }^{* * *}: P \leq 0.001$.

\begin{tabular}{|c|c|c|c|c|c|c|}
\hline & $\mathrm{N}$ & A & AP & JP & $\mathrm{mTJ}$ & MTJ \\
\hline S. armeniacus & 15 & $\begin{array}{l}616 \\
(488 / 767)^{\text {sp, ss, St }}\end{array}$ & $\begin{array}{l}542 \\
(511 / 592)^{\mathrm{Sv}}\end{array}$ & $\begin{array}{l}42 \\
(34 / 44)\end{array}$ & $\begin{array}{l}-3.6 \\
(-4.6 /-1.8)^{\mathrm{sp}, \mathrm{Sv}}\end{array}$ & $\begin{array}{l}26.7 \\
(24.5 / 28.2)\end{array}$ \\
\hline S. variolosus & 53 & $\begin{array}{l}327 \\
(180 / 584)^{\mathrm{St}}\end{array}$ & $\begin{array}{l}1072 \\
(683 / 1312)^{\mathrm{Sa}, \mathrm{Sp}, \mathrm{Ss}, \mathrm{St}}\end{array}$ & $\begin{array}{l}30 \\
(18 / 46)^{\mathrm{St}}\end{array}$ & $\begin{array}{l}1.3 \\
(0.2 / 2.5)^{\mathrm{Sa}, \mathrm{Sp}, \mathrm{Ss}, \mathrm{St}}\end{array}$ & $\begin{array}{l}28.4 \\
(27 / 30)\end{array}$ \\
\hline S. pius & 49 & $\begin{array}{l}232 \\
(132 / 416)^{\mathrm{sa}}\end{array}$ & $\begin{array}{l}574 \\
(515 / 674)^{\mathrm{Sv}}\end{array}$ & $\begin{array}{l}37 \\
(31 / 46)\end{array}$ & $\begin{array}{l}-1.1 \\
(-2.5 / 0.2)^{\mathrm{Sa}, \mathrm{Sv}}\end{array}$ & $\begin{array}{l}28.5 \\
(26.7 / 29.6)\end{array}$ \\
\hline S. sacer & 23 & $\begin{array}{l}206 \\
(109 / 461)^{\mathrm{Sa}}\end{array}$ & $\begin{array}{l}592 \\
(563 / 674)^{\mathrm{Sv}}\end{array}$ & $\begin{array}{l}34 \\
(30 / 47)\end{array}$ & $\begin{array}{l}-1.8 \\
(-2.8 /-0.2)^{\mathrm{sv}}\end{array}$ & $\begin{array}{l}27.9 \\
(27.0 / 29.8)\end{array}$ \\
\hline S. typhon & 93 & $\begin{array}{l}158 \\
(80 / 316)^{\mathrm{sa}, \mathrm{sv}}\end{array}$ & $\begin{array}{l}589 \\
(531 / 709)^{\mathrm{sv}}\end{array}$ & $\begin{array}{l}44 \\
(32 / 51)^{\mathrm{sv}}\end{array}$ & $\begin{array}{l}-2.0 \\
(-3.3 /-0.1)^{\mathrm{sv}}\end{array}$ & $\begin{array}{l}27.9 \\
(27.1 / 28.8)\end{array}$ \\
\hline $\mathrm{KW}$ & & $30.6^{* * *}$ & $35.3^{* * *}$ & $10.7^{*}$ & $55.0^{* * *}$ & 8.7 \\
\hline
\end{tabular}

(Hirzel et al. 2004). For each species this analysis allows us to select the most relevant variables from all those considered. Thus, the variables with factor scores higher than 0.30 that in turn were not highly correlated between them (absolute Pearson correlation values lower than 0.90 ) were selected.

Once the most relevant environmental variables were selected for each of the five Bulgarian Scarabaeaus species, they were used to estimate the Mahalanobis Distance (Farber \& Kadmon 2003) between the climatic conditions present in known cells containing the species and the whole considered territory. This measured distance differs from the Euclidean one in that it takes into account the dependence among variables and is scale-invariant (i.e. the variables have the same weight independently of their variance). Once rescaled to a 0 to 100 interval, this environmental distance from presence localities was used as a measure of climatic favourability. The $10^{\text {th }}$ percentile of these distances (the values below which 10 percent of observations may be found) were arbitrarily mapped and considered as the most climatically favourable areas for each species. In all occasions doubtful or imprecise species localities were discarded and although map representations were focused on the Bulgarian territory, calcula- tions were carried out considering the complete data mentioned in the text, including those from other adjacent countries.

For each locality with the presence of Scarabaeus, we finally extracted the values of the variables detected more frequently as relevant by ENFA analyses (altitude, annual precipitation, July precipitation, minimum temperature in January and maximum temperature in July). These values were compared among species by a nonparametric Kruskal-Wallis ANOVA test in order to detect the statistically significant differences in environmental conditions that prevail in those cells inhabited by the five species.

\section{Results}

\subsection{Basic information on the species}

\subsubsection{Scarabaeus (Ateuchetus) armeniacus}

Ménétriés, 1832 [= puncticollis Auct.nec (Latreille, 1819)]

Literature data. Bulgaria. Scarabaeus puncticollis: Pittioni 1940: 219 (Dragoman; Pazardzhik; Slavyanka Mt.); Csiki 1943: 215 (Slavyanka Mt., 1,000-1,500 m); Angelov 1965: 101 


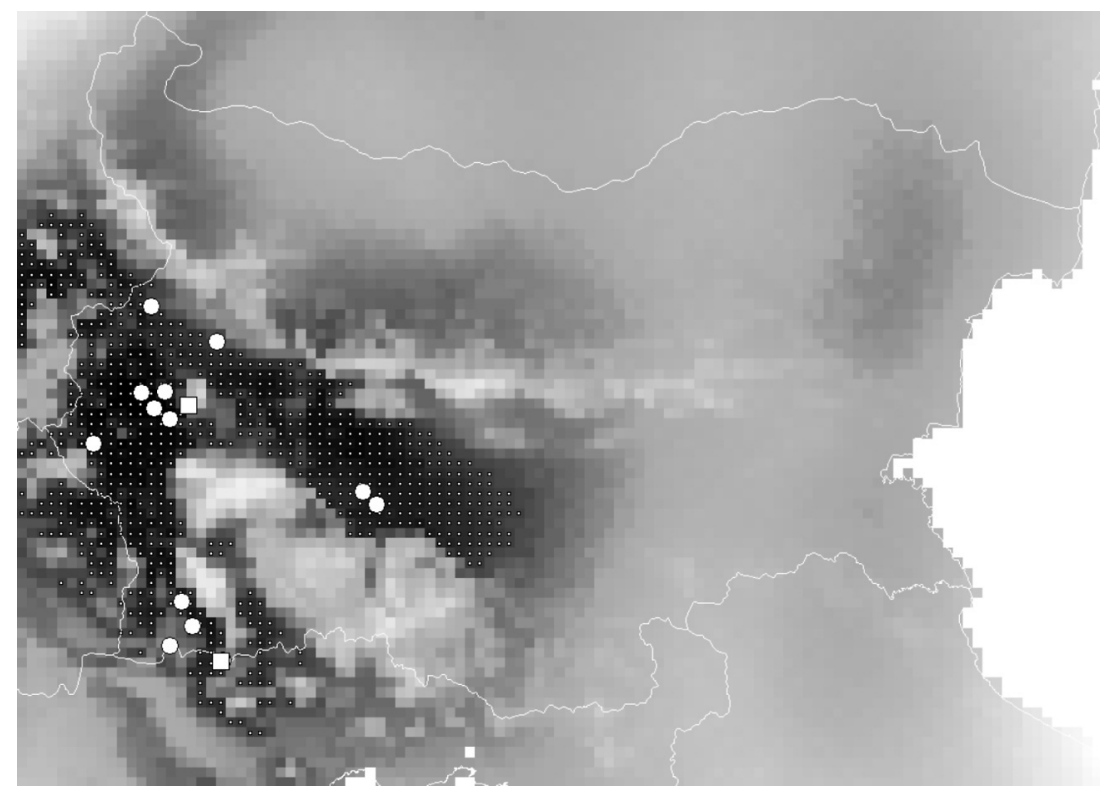

Fig. 2. Distribution map of Scarabaeus armeniacus in Bulgaria and adjacent areas. White circles represent the well-known localities while white squares are doubtful or imprecise localities. Grey tones represent the favourability for species occurrence (scale 0100 ) according to the Mahalanobis distance from the climatic conditions in presence localities varying from black (low distance or high favourability) to white (high distance or low favourability). Little white dots represent the values below $10^{\text {th }}$ percentile (the most favourable). UTM projection at a cell resolution of $5 \times 5 \mathrm{~km}$.

(Ognyanovo near Pazardzhik; Novi Iskar (= Kurilo)); Kyustendil; Golo Bardo Mt.); Zacharieva 1965c: 230 (Pazardzik; Elin Vrah near Ognyanovo); Zaharieva, Dimova 1980: 18 (Drangovo); Zaharieva, Dimova 1981: 90 (Drangovo). Scarabaeus armeniacus: Král, Malý 1993: 21 ((Bornarevo (= Bomarevo); Dolna Dikanya; Lilyanovo; Melnik). Macedonia. Scarabaeus puncticollis: Mikšić 1953: 57 (Prilep); Mikšić 1955: 229 (Bitolja).

New data. Bulgaria. Golo Bardo Mt:: Radomir, 28.IV.1937, 1 s., P. Drenski leg. / Gradishte, 29.IV.1937, 2 s., P. Drenski leg.; Slavyanka Mt., 18.VI.1959, 2 s., A. Prostov leg.; Vitosha Mt., 19.VII.1961, 1 s., S. Minkova leg. Macedonia. Bitolja, VI.1917, 1 s., P. Drenski leg.

Altitudinal range. From $400 \mathrm{~m}$ (Melnik) to 1,500 m (Slavyanka Mt.), although this last citation lacks details. Most occurrence records range from approximately 490 to $770 \mathrm{~m}$ (Table 2).

Seasonality. From April to July.

Material examined. 13 specimens.

Comments. The data from the Slavyanka Mt.
(Pittioni 1940, Csiki 1943) and Vitosha Mt. are not used in the estimation of the potential distribution by the lack of a precise locality. According to Löbl et al. (2006) and Schoolmeesters (2007) this species is distributed across Azerbaijan, Armenia, Bulgaria, Georgia, Greece, Macedonia, South Russia, Ukraine, Cyprus, Iran, Iraq, Israel, Egypt (Sinai), Syria and Turkey.

In Bulgaria this species seems to be confined to the south-western portion of the country, in the Struma, Maritsa, Iskar and Nishava valleys. This species does not seem to colonize the relatively climatically suitable areas far away from the Stara Planina Mts. (Fig. 2).

\subsubsection{Scarabaeus (Ateuchetus) variolosus Fabricius, 1787}

Literature data. Albania. Scarabaeus variolosus: Mikšić 1953: 57 (Berat; Vlorë (= Valona)); Dukati; Kanine; Maj' e Kjores (= Kjores Mt.); Mikšić 1959: 50 (Liquen i Butrintit; Llogora); Balthasar, Hrubant 1960: 147 (Liquen i Butrintit; 
Llogora). Bosnia-Herzegovina. Scarabaeus variolosus: Mikšić 1953: 57 (Mostarsko Blato; Mostar; Velež Mt.; Podvelež; Donje Hrasno; Ljubinje; Bileće; Trebinje). Bulgaria. Scarabaeus variolosus: Nedelkov 1905: 19 (Samokov); Pittioni 1940: 219 (Belasitsa Mt.). Croatia. Scarabaeus variolosus: Mikšić 1953: 57 (Rijeka; Grižane; Krasica; Crikvenica; Novi Vinodolski; Senj; Cres; Baška Nova - Krk Island; Lakmartin; Babin Dub; Knin; Trogir; Starigrad - Hvar Island; Vrgorac - Propotnica); Mikšić 1957: 142 (Biokovo Mt.); Mikšić 1959: 50 (Meja; Bakar; Kraljevica; Bokanjac; Dugi Otok; Metkovic). European Turkey. Scarabaeus variolosus: Pittioni 1940: 219 (Kuru Dagh Mt.). Greece. Scarabaeus variolosus: Pittioni 1940: 219 (Oktchilar near to Xanthi; Eleftera Monastery); Mikšić 1953: 57 (Korfu Island; Chani Driskos near Janina; Hortiatis Mt.; Velestino; Stylis; Parnass Mt.; Kiphissia; Athens; Tripolis; Syra Island; Crete Island); Mikšić 1957: 142 (Volo; Pelion Monastir Survias); Mikšić 1959: 50 (Lianikladia near Kamia; Delphi; Amphissa; Zachlorou; Megaspilaon; Nauplia; Limenaria-Thasos Island; Rhodos Island). Montenegro. Scarabaeus variolosus: Mikšić 1953: 57 (Sutorman; Titograd).

New data. Greece. Kavala, 18.IV.1943, 1 s., N. Karnoshitsky leg.; Thasos Island, Theologos, 2.V.1943, 2 s., N. Karnoshitsky leg.

Altitudinal range. Most known records range from 180 to $580 \mathrm{~m}$ (Table 2).

Seasonality. From April to July, also in October.

Material examined. 16 specimens.

Comments. In our opinion the locality near Samokov (Nedelkov 1905) is rather doubtful (see also Mikšić 1959: 50). The occurrence of this species in Bulgaria needs to be confirmed. Löbl et al. (2006) and Schoolmeesters (2007) recognize their presence from Albania, Algeria, BosniaHerzegovina, Bulgaria, Croatia, Greece, Italy, Malta, Morocco, Sardinia, Serbia, Sicily, Tunisia and Turkey.

The areas climatically suitable for this species seem to be limited to the southern border of Bulgaria. The northernmost favourable localities are along the southern Black Sea coast, the Maritsa valley and mainly along the Struma valley (Fig. 3). The few Bulgarian records for this species outline its marginal distribution there, occupying probably the most extreme cold climate conditions for this Mediterranean species.

\subsubsection{Scarabaeus (Scarabaeus) pius (Illiger, 1803)}

Literature data. Albania. Scarabaeus pius: Mikšić 1953: 56 (Oroshi). Bosnia-Herzegovina. Scarabaeus pius: Mikšić 1953: 56 (Mostarsko Blato; Domanovići; Stolac); Mikšić 1959: 50 (Klobuk). Bulgaria. Ateucus pius: Joakimov 1899: 7 ("common species inhabiting between Dupnitsa and the Rilski Manastir"). Scarabaeus pius: Nedelkov 1905: 19 (Rila Mt.); Pittioni 1940: 218-219 ((Lyulin Mt.; Asenovgrad (= Stanimaka); Plovdiv; Parvenets (= Ferdinandovo); Sliven; Turia; Peshtera; Rila Mt.; Vitosha Mt.; Burgas; Belasitsa Mt.; Slavyanka Mt.)); Csiki 1943: 215 (Marino Pole; Petrovo); Mikšić 1959: 49 (Asenovgrad (= Stanimaka)); Angelov 1960: 22 (Ostrova Place in Plovdiv); Muche 1964: 61 (Nesebar); Angelov 1965: 102 (Hrabrino; Gara Krichim); Zacharieva 1965b: 129 (Mandritsa; Meden Buk; Kardzhali); Zaharieva 1965c: 230 (Sestrimo; Harmanli); Zaharieva et al. 1975: 31 (Primorsko; outfall of Kamchia River); Zaharieva, Dimova 1980: 18 (Drangovo); Zaharieva, Dimova 1981: 90 (Drangovo); Bunalski 2000: 88 (Kozhuh Hill). Croatia. Scarabaeus pius: Mikšić 1953: 56 (Grižane; Grobnik; Novi Vinodolski; Split; Dubrovnik); Mikšić 1959: 50 (Rijeka; Crikvenica). Greece. Scarabaeus pius: Pittioni 1940:218-219(Chamkjoiski Momastery near Soufli; Soufli; Xanthi; Athens - Pentelikon); Karnoschitzky 1959: 244 (Limenaria - Thasos Island); Mikšić 1953: 56 (Phaleron; Athens Pentelikon; Kiphissia); Mikšić 1957: 142 (Ossa Mt.; Volo); Mikšić 1959: 50 (Zachlorou; Limenaria). Macedonia. Scarabaeus pius: Mikšić 1953: 56 (Gevgelja); Mikšić 1955: 229 (Gara Pcinja; Gevgelja). Montenegro. Scarabaeus pius: Mikšić 1959: 50 (Kotor). Romania. Scarabaeus pius: Netolitzky 1912: 163 (Turno-Severin); Panin 1957: 57 (Techirghiol; Constantsa). Serbia. Scarabaeus pius: Mikšić 1953: 56 (VojvodinaSušara); Mikšić 1959: 50 (Grebenac - Vojvodina Region).

New data. Bulgaria. Petrich, 20.IV.19??, 1 s., A. Martino leg.; Kresna (= Gara Pirin), 


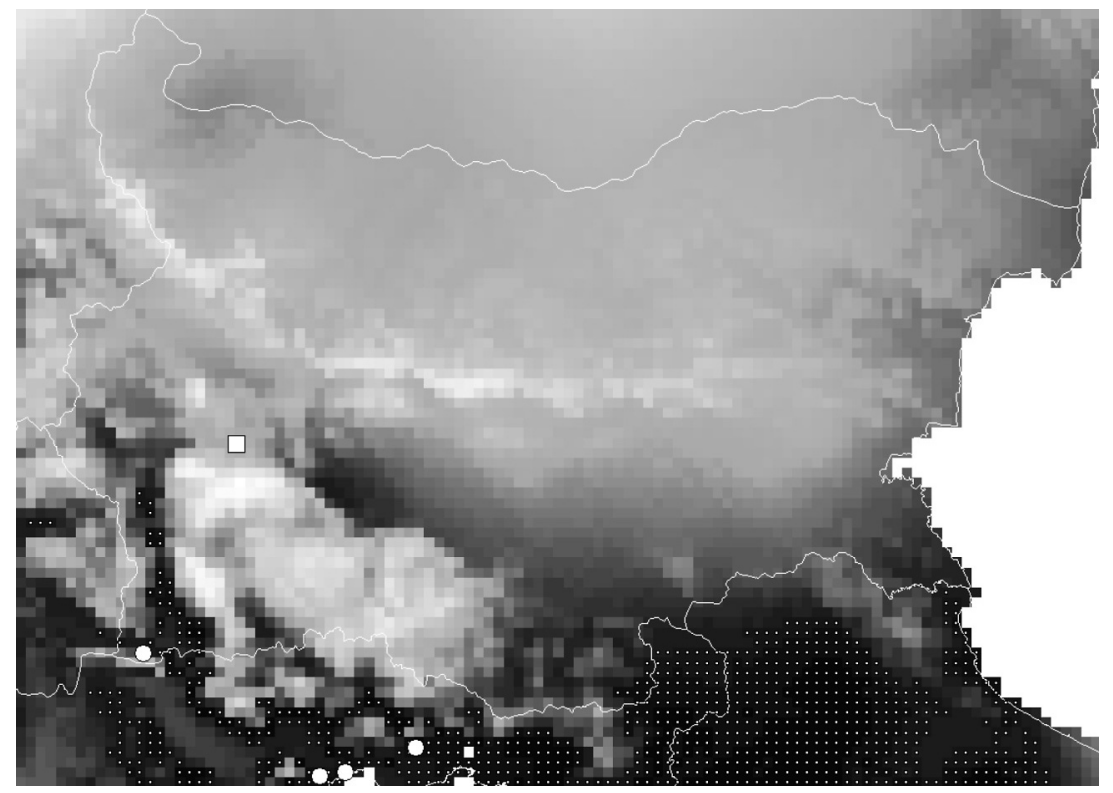

Fig. 3. Distribution map of Scarabaeus variolosus in Bulgaria and adjacent areas. White circles represent the well-known localities while white squares are doubtful or imprecise localities. Grey tones represent the favourability for species occurrence (scale 0-100) according to the Mahalanobis distance from the climatic conditions in presence localities varying from black (low distance or high favourability) to white (high distance or low favourability). Little white dots represent the values below $10^{\text {th }}$ percentile (the most favourable). UTM projection at a cell resolution of $5 \times 5 \mathrm{~km}$.

24.VI.1935, 1 s., Tuleshkov; Petrich, 14.V.1955, 3 s., A. Prostov leg.; Bachkovski Monastery, VI.1956, 1 s., I. Belog leg.; Slavyanka Mt., 18.VI.1959, 3 s., A. Prostov; Kresna Gorge, 23.VI.1959, 1 s., A. Prostov leg. / 12.VI.1966, 1 s., D. Lukov leg.; Lebnitsa in Ograzhden Mt., 300-500 m, 25.IV.1985, 1 s., M. Josifov leg; Kresna, 200-250 m, 1.VI.1993, 1 s., B. Guéorguiev leg; Simitli, 5.V.2002, 1 s., E. Migliaccio leg; Struma Valley: Kamenitsa Village, 170-240, 9.V.2002, 1 s., E. Migliaccio; SE slope of Sveti Illya Hill, near Kalimantsi, 450-510 m, 10 11.V.2002, 4 s., E. Migliaccio leg. / 10.V1.VI.2002, 7 s. in soil traps, M. Langourov leg.; Kalimantsi, 12.V.2002, 1 s., E. Migliaccio leg; Maleshevska Planina along Gornobrezdnishka River, 200-550 m, 15.VI.2002, 1 s., B. Guéorguiev leg; Maleshevska Planina, west of G. Breznitsa, 600-1,000 m, 9.VII.2002, 1 s., B. Guéorguiev; Maleshevska Planina, north of Gornobreznishka River, 600-1,000 m, 11.VII. 2002, 1 s., B. Guéorguiev leg; Maleshevska Planina, west of Valkovo, 190 m, 4.VII-8.VIII.2003, 1 s., B.
Guéorguiev leg. Greece. Gerakas - Sminthi, 11.V.2006, 1 s., P. Beron leg.

Altitudinal range. Most records are from sea level to 1,000 m (Slavyanka Mt., cfr. Pittioni 1940). The latter author (op. cit.) recorded S. pius from the Vitosha Mt., at 1,300 $\mathrm{m}$ above sea level, and Joakimov (1899) cite the species as living near the Rilski Monastery, ca. 1,400 m. In our opinion, these two last records are doubtful. In general, most of the records range from approximately 130 to $410 \mathrm{~m}$ (Table 2).

Seasonality. From April to August, also in November.

Material examined. 113 specimens.

Comments. Several records are doubtful or imprecise (Lyulin Mt., Pittioni 1940; Vitosha Mt., Pittioni 1940; Rila Mt., Nedelkov 1905 and Pittioni 1940; Belasitsa Mt., Pittioni 1940; Slavyanka Mt., Pittioni 1940). The material published by Markovich (1904: 239 sub Ateucus pius) and Markovich (1909: 10 sub Ateucus pius) from the vicinity of Razgrad does not belong to the genus Scarabaeus. Löbl et al. (2006) and 


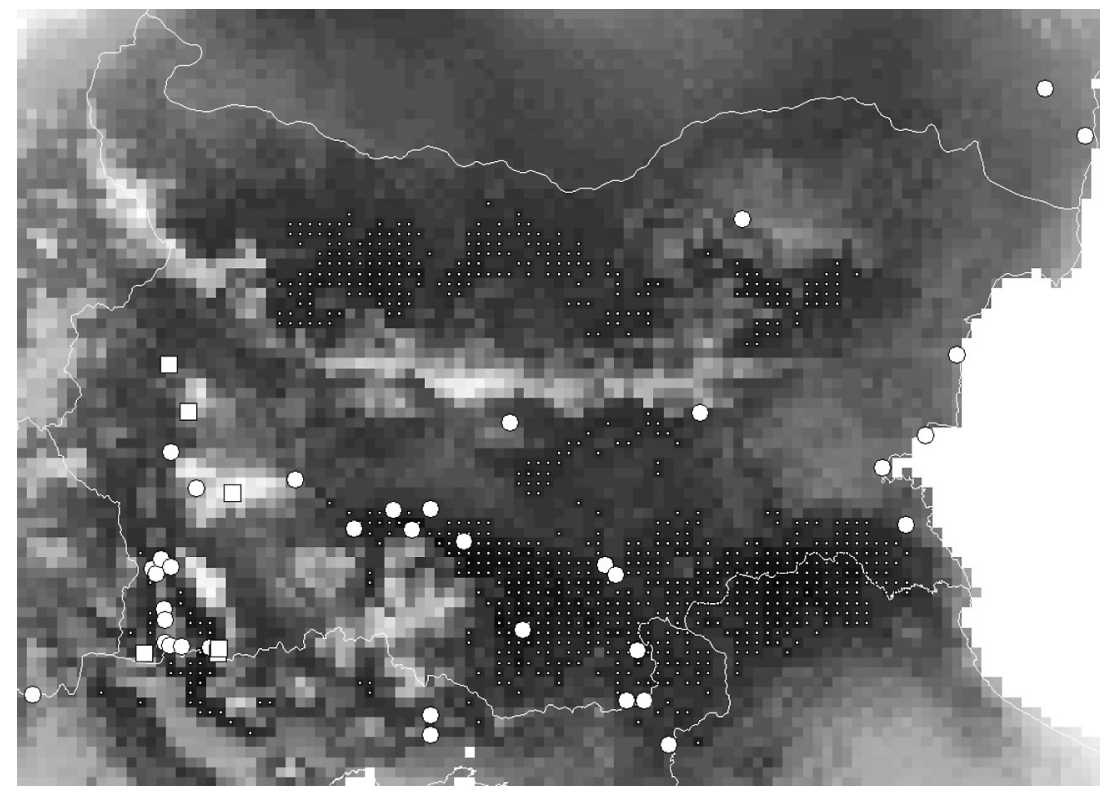

Fig. 4. Distribution map of Scarabaeus pius in Bulgaria and adjacent areas. White circles represent the well-known localities while white squares are doubtful or imprecise localities. Grey tones represent the favourability for species occurrence (scale 0-100) according to the Mahalanobis distance from the climatic conditions in presence localities varying from black (low distance or high favourability) to white (high distance or low favourability). Little white dots represent the values below $10^{\text {th }}$ percentile (the most favourable). UTM projection at a cell resolution of $5 \times 5 \mathrm{~km}$.

Schoolmeesters (2007) mention S. pius from Afghanistan, Albania, Anatolia, Andorra, Armenia, Austria, Azerbaijan, Bulgaria, Croatia, Caucasus, France, Georgia, Greece, Hungary, Iran, Israel, Italy, Jordan, Kazakhstan, Lebanon, Macedonia, Palestine, Romania, South Russia, Serbia, Spain, Syria, Tajikistan, Turkey, Turkmenistan and Uzbekistan.

This species seems to be distributed both in southern (Struma or Maritsa valleys) and in northern (Danube Plain) localities situated on both sides of the Stara Planina Mts. (Fig. 4), as well as in proximity to or along the Black Sea coast. The current occurrence in the northernmost climatically favourable Bulgarian regions needs to be confirmed.

\subsubsection{Scarabaeus (Scarabaeus) sacer}

Linnaeus, 1758

Literature data. Albania. Scarabaeus sacer: Mikšić 1953: 55 (Durres; Vlorë (= Valona)). Bulgaria. Ateuchus sacer: Markovich 1904: 239 (Razgrad env.); Markovich 1909: 10 (Razgrad).
Scarabaeus sacer: Nedelkov 1909: 97 (Stara Zagora, based on remains of single specimen); Pittioni 1940: 217 (Novi Iskar (= Kurilo)); Sliven; Burgas; Nesebar; Primorsko (= Kyupria); Malko Tarnovo; Blagoevgrad - Parangalitsa); Drenski 1942: 40 (north of Varna); Mikšić 1953: 55 (Burgas); Angelov 1960: 22 (Ostrova Place in Plovdiv); Muche 1964: 61 (Nesebar); Zacharieva 1965a: 141 (Sredets = Grudovo); Zacharieva 1965c: 230 (Muldava); Trifonov 1966: 1074 (Strandzha); Zacharieva et al. 1975: 31 (Primorsko (= Stamopolu); Guéorguiev 2001: 171 (place Stara Kresna above Kresna Town). Greece. Scarabaeus sacer: Mikšić 1953: 55 (Zante); Mikšić 1959: 49 (Asteri near Skala Elos District in Lakonia; Chalkis - Euboea Island; Askifou at Lefka Ori, 1,200-2,000 m, Crete Island; Rhodos Island). Montenegro. Scarabaeus sacer: Mikšić 1953: 55 (Krasići). Romania. Scarabaeus sacer: Netolitzky 1912: 163 (TurnoSeverin).

New data. Bulgaria. Nesebar, 22.V.1922, 1 s., D. Joakimov leg.; Strandzha Mt., Ravna Gora, 


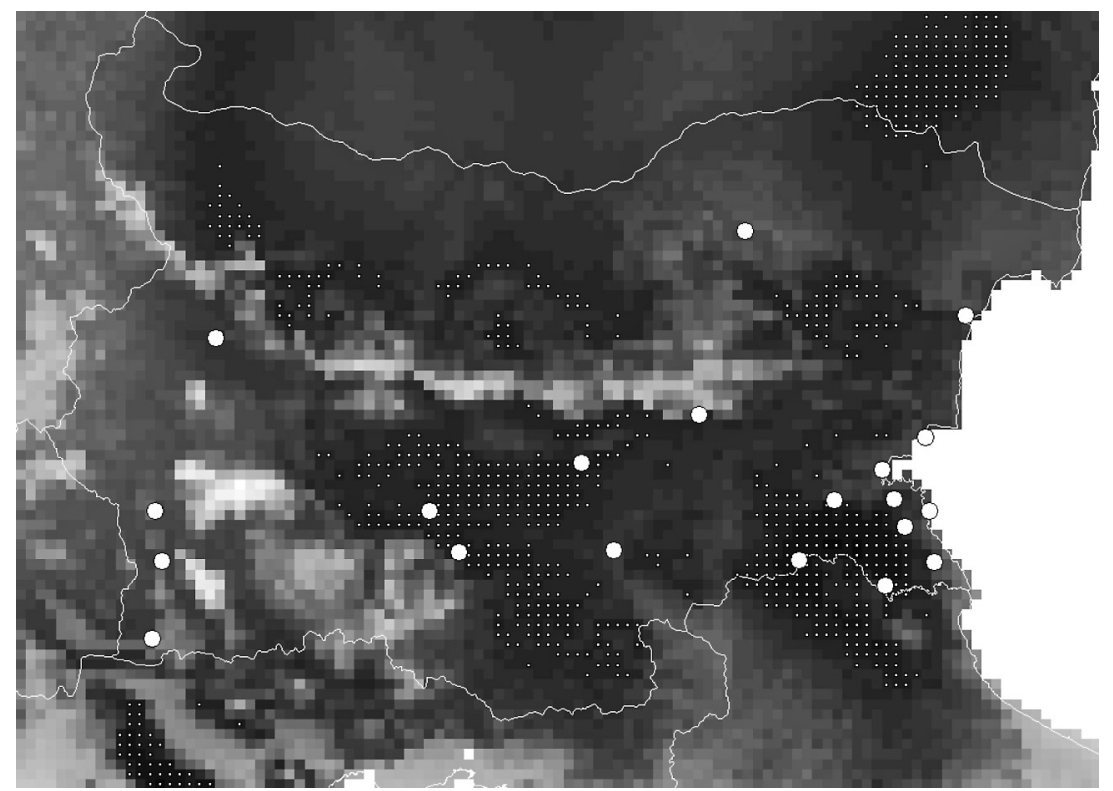

Fig. 5. Distribution map of Scarabaeus sacer in Bulgaria and adjacent areas. White circles represent the well-known localities while white squares are doubtful or imprecise localities. Grey tones represent the favourability for species occurrence (scale 0-100) according to the Mahalanobis distance from the climatic conditions in presence localities varying from black (low distance or high favourability) to white (high distance or low favourability). Little white dots represent the values below $10^{\text {th }}$ percentile (the most favourable). UTM projection at a cell resolution of $5 \times 5 \mathrm{~km}$.

21.VI.1923, 1 s., Ilchev leg; Varna, 1.V.1936, 1 s., / 9.V.1940, 1 s., / 27.VI.1953, 1 s., N. Karnoschitsky leg; Ropotamo, 5.V.1957, 1 s., A. Valkanov; Simeonovgrad, 20.V.1940, 4 s., N. Karnoschitsky leg; Struma Valley: "Sv. Vargoo" near Petrich, 1.VII.1941, 2 s., I. Buresh leg; Primorsko, 25.VI.1954, 2 s., T. Marinov leg. / 13.VII.1955, 3 s., Vichodzevsky leg.; Malko Tarnovo, 2.VII.1955, 2 s.; Primorsko, 29.VI. 1958, 1 s., Karnoschitsky leg.

Altitudinal range. Most of the recorded localities are distributed from 100 to $460 \mathrm{~m}$ (Table 2). The localities near Malko Tarnovo and Novi Iskar (cfr. Pittioni, 1940; our present data) seem to be the highest ones (around $600 \mathrm{~m}$ ).

Seasonality. from April to October

Material examined. 35 specimens.

Comments. According to Stolfa (1938) and Mikšić (1953) this species is confined to the southern and eastern regions of the Balkan Peninsula. Löbl et al. (2006) and Schoolmeesters (2007) mention the species from Afghanistan, Albania, Algeria, Armenia, Azerbaijan, Bulgaria,
Caucasus, China Northeast, Corsica, Egypt, Sinai, France, Greece, Hungary, India (Kashmir), Iraq, Iran, Israel, Italy, Jordan, Libya, Morocco, Pakistan, Palestine, Portugal, Romania, South Russia, Sardinia, Saudi Arabia, Serbia, Sicily, South Siberia, Spain, Syria, Transcaspia, Tunisia, Turkistan, Turkey and Ukraine.

In Bulgaria the known records of this species are mainly located in the lowlands to the south of the Stara Planina Mts. (Struma, Maritsa and Tundzha valleys), near the Black Sea coast, but also in the lowlands near the Turkish boundary (Fig. 5). However, there are also climatically favourable potential areas in some northern lowlands, albeit without currently detected populations.

\subsubsection{Scarabaeus (Scarabaeus) typhon (Fischer von Waldheim, 1824) [= affinis (Brullé, 1832)]}

Literature data. Albania. Scarabaeus afiinis: Mikšić, 1959: 49 (Vlorë); Balthasar, Hrubant 
1960: 147 (Vlorë). Bosnia-Herzegovina. Scarabaeus afiinis: Mikšić 1953: 56 (Mostar; Hutovo Blato; Neum; Trebinje); Mikšić 1959: 49 (Klobuk). Bulgaria. Scarabaeus afiinis: Stolfa 1938: 149 (Asenovgrad (= Stanimaka)); Pittioni 1940: 217 (Lom; Vidin; Stara Zagora; Krichim; Peshtera; Kazanlak; Sadovo; Turia; Sliven; Pazardzhik; Vitosha (dubious locality!); Evksinograd; Burgas; Meden Rudnik (= Karabair); Rezovo; Strandzha Mt.; Petrich); Mikšić 1953: 56 (Akrianu; Varna); Mikšić 1959: 49 (Asenovgrad (= Stanimaka)); Muche 1964: 61 (Nesebar); Angelov 1965: 102 (Mitino in Petric District, not "Mitinovo"); Zacharieva 1965b: 129 (Kamilski Dol Place near Ivaylovgrad; Krumovgrad; Mandritsa; Podkova); Dimitrova, Genov 1966: 1216 (Grudovo; Belila); Dimitrova, Genov 1968: 81 (Grudovo; Belila); Zaharieva 1974: 123-124 (Venets near Burgas); Zaharieva, Dimova 1975: 184 (Mandritsa; Orlitsa); Zaharieva, Dimova 1980: 18 (Drangovo); Zaharieva, Dimova 1981: 90 (Drangovo). Scarabaeus typhon: Bunalski 2000: 88 (Kozhuh Hill; Arkutino). Croatia. Scarabaeus afiinis: Mikšić 1953: 56 (Grobnik; Vinodol; Obrovac; Visoko; Bokanjac; Dubrovnik); Mikšić 1957: 141 (Nadimsko Blato); Mikšić 1959: 49 (Kraljevica). European Turkey. Scarabaeus afiinis: Pittioni 1940: 217 (Merefte near Sharkjoi). Greece. Scarabaeus afiinis: Pittioni 1940: 217 (Eleftera Monastery); Mikšić 1953: 56 (Stylis; Velouhi Mt.; Peloponnese; Tripolis; Naxos Island); Mikšić 1957: 141 (Ossa Mt.; Volo); Mikšić 1959: 49 (Zante; Cyclades Islands; Syra Island; Rhodops Island). Kosovo. Scarabaeus afiinis: Mikšić 1953: 56 (Gračanica). Macedonia. Scarabaeus afiinis: Mikšić 1953: 56 (Gevgelija); Mikšić 1955: 229 (Zelenikovo; Gevgelija); Mikšić 1957: 141 (Vodoca; Stari Dojran). Montenegro. Scarabaeus afiinis: Mikšić 1957:141 (Virpazar). Romania. Scarabaeus afiinis: Panin 1957 (Constantsa; Vasile-Roaita; Hirshova; Agigea; Istria; Letea; Cardon; Tulcea; Braneshti; Tecuci; Calarashi; Calafat; Sadova; Jiana Mare; Bucharest). Serbia. Scarabaeus afiinis: Mikšić 1953: 56 (Vojvodina - Mramorak; Vojvodina Sušara; Požarevats; Zatonje near Veliko Gradište; Niš; Bela Palanka; Kosovo Polje-Gračanica); Mikšić 1957: 141 (Usje; Ram; Vince); Mikšić 1959: 49 (Vojvodina - Palić; Vojvodina Horgos near Grebenac).
New data. Bulgaria. Bratsigovo, 1 s., A. Markovich leg; Varna, 1 s., A. Markovich leg.; Perushtitsa, VII.1921, 2 s., Sakazov leg; Turia, 2.VI.1923, 1s., D. Joakimov leg; Shtit (= Yuskudar) near Svilegrad, 23.VI.1928, 2 s., P. Tchorbadjiev leg; Harmanli, VI.1939, 1 s., Drenski leg / 22.V.1949, 1 s.; Struma Valley: "Sv. Vargoo" near Petrich, 1.VII.1941, 2 s., I. Buresh leg.; Burgas, 1.V.1948, 1 s., N. Karnoshisky; Beloslav, 27.VI.1948, 1 s., N. Karnoshisky / 2.VII.1953, 1 s., A. Valkanov / 9.V.1954, 1 s., T. Marinov; Zvezditsa near Varna, 2.V.1949, 1 s., N. Karnoshisky leg; Dulovo, 14.VI.1952, 1 s., Drenski leg; Nesebar, 23.VI.1953, 1 s., A. Valkanov; Varna, 9.X.1955, 2 s., N. Karnoshisky; Hisar, 15.X.1955, 1 s., Karnoshisky leg; Petrich, 23.VI.1957, 1 s., A. Prostov leg. / 15.VI.1959, 1 s., G. Peshev leg.; Karnobat, 17.6.1967, 1 s., B. Zaharieva leg; Kamchia, 13.VI.1968, 1 s., B. Zagarieva; Kamenitsa Vill. in Struma valley, 170 240, 9.V.2002, 1 s., E. Migliaccio; SE slope of Sveti Illya Hill, near Kalimantsi, 450-510 m, 10.V-1.VI.2002, $3 \mathrm{~s}$. in soil traps, M. Langourov leg. / 22.V-6.VIII.2002, 4 s., D. Chobanov leg. Greece. Thasos Island, Limenaria, 1.5.1943, 1 s., N. Karnoshisky leg. Serbia. Dimitrovgrad (= Tsaribrod), 1 s., N. Bahmetiev leg.

Altitudinal range. Most of the recorded localities range from approximately 80 to $320 \mathrm{~m}$ (Table 2).

Seasonality. from May to August, also in October.

Material examined. 97 specimens.

Comments. The recorded specimen from "Vitosha" (Pittioni, 1940) is doubtful and/or imprecise. Löbl et al. (2006) and Schoolmeesters (2007) recognize the species from Afghanistan, Albania, Armenia, Asia Minor, Azerbaijan, Bosnia-Herzegovina, Bulgaria, Central Asia, Corsica, Croatia, Cyprus, France, Georgia, Greece, Hungary, Iran, Iraq, Israel, Italy, Jordan, Kazakhstan, Lebanon, Macedonia, Mongolia, Morocco, North Korea, Portugal, Rhodes, Romania, Sardinia, Serbia, Slovakia, South Korea, South Russia, Spain, Syria, Turkey, Turkmenistan, Ukraine, Uzbekistan and China (Xinjiang and Xizang).

The known records for this species are distributed along the south-western Struma and Mesta valleys, the south-eastern areas near the Maritsa valley and the Black Sea coast, as well as in some 


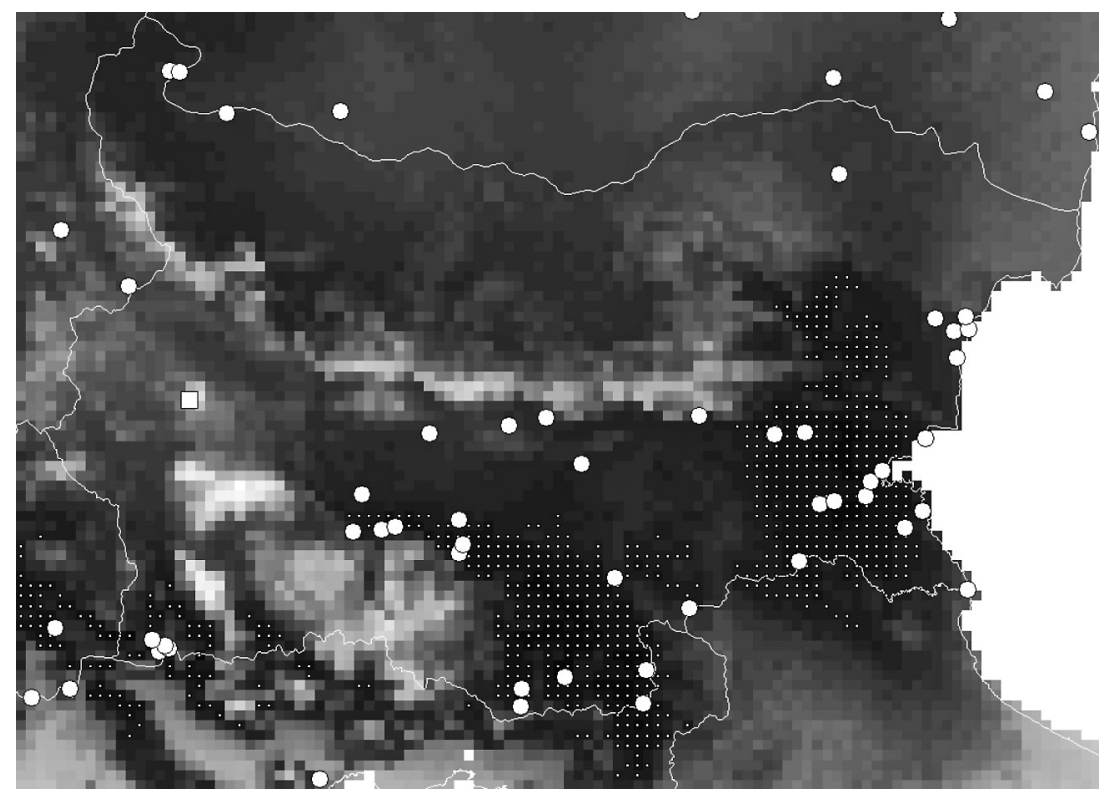

Fig. 6. Distribution map of Scarabaeus typhon in Bulgaria and adjacent areas. White circles represent the well-known localities while white squares are doubtful or imprecise localities. Grey tones represent the favourability for species occurrence (scale 0-100) according to the Mahalanobis distance from the climatic conditions in presence localities varying from black (low distance or high favourability) to white (high distance or low favourability). Little white dots represent the values below $10^{\text {th }}$ percentile (the most favourable). UTM projection at a cell resolution of $5 \times 5 \mathrm{~km}$.

northern localities near to the Danube River and lowlands located on the southern slopes of the Stara Planina Mts. However, the most climatically favourable areas are those located in the southern and eastern lowland areas (Fig. 6), although some records from northern Bulgaria seem to be associated with localized xerothermic microhabitats, situated within relatively unsuitable zones of temperate climate.

\subsection{Temporal distribution of records}

The temporal distribution of Scarabaeus records concerning Bulgaria and neighbouring territories shows that the distributional information on these species increased gradually until the 1960's at an approximate rate of 25 records per decade, diminishing since then to a rate of 9 records per decade mainly due to the collection of S. pius (Fig. 7). Most of the remaining species display a low or even no rate of increase in the number of records since the sixties. Only one specimen of $S$. sacer and none of $S$. variolosus have been recorded during the last forty years.

During the first two decades of the $20^{\text {th }}$ century, N. Nedelkov, a prominent pioneer of Bulgarian entomology, collected most of the known specimens of Scarabaeus in Bulgaria. This prom-

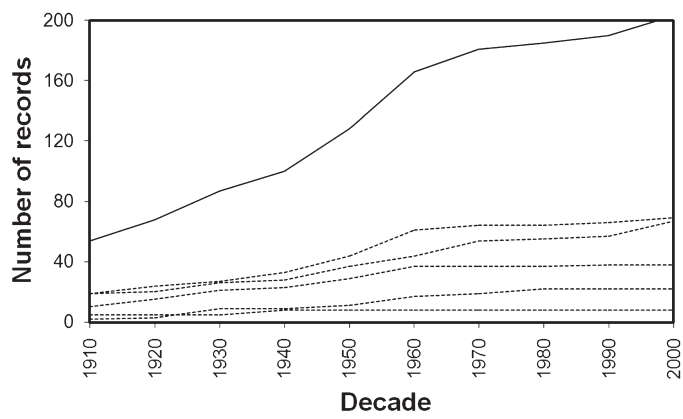

Fig. 7. Accumulative increase in the total number of records of Bulgarian Scarabeus species across decades (continuous line) and for each species (discontinuous lines). Order of the species, from top to bottom: S. typhon, S. pius, S. sacer, S. armeniacus and S.variolosus. 
Fig. 8. Range ellipses of winter minimum mean temperature and annual precipitation values for the available presence data of the five Bulgarian Scarabaeus species. The ellipses include $99 \%$ of the data. Precipitation and temperature were selected because of their higher discrimination capacity than with the rest of the climatic variables (see Table 2).

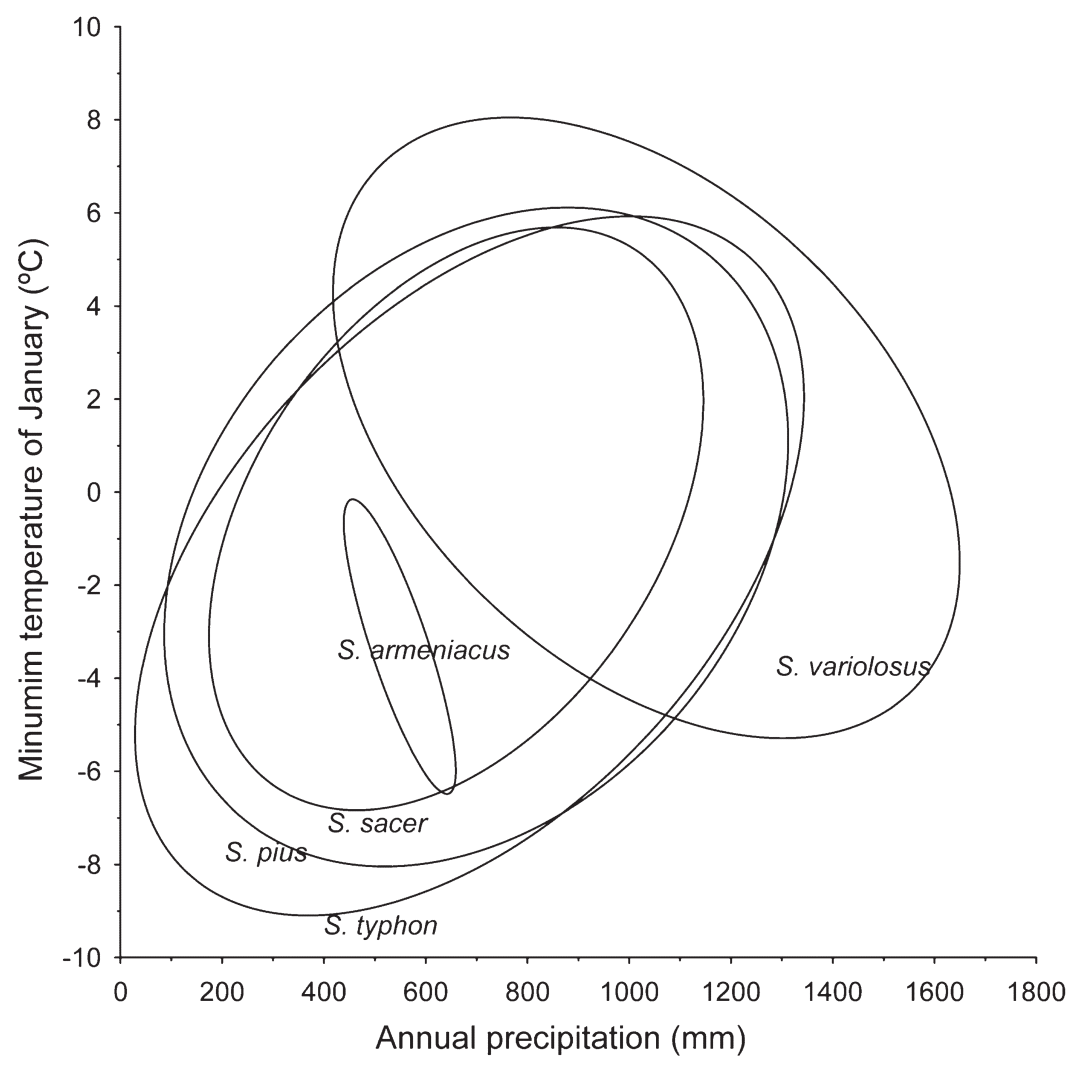

inent work was followed by the sampling carried out by other entomologists such as I. Buresch, D. Joakimov, A. Markovich and D. Tschorbadjiev. In the decades of 1950-1960 and 1960-1970 most records came from the fieldwork accomplished by B. Zaharieva, the most well known native specialist of Bulgarian dung beetles.

\subsection{General environmental adaptations}

Mean maximum temperatures for July in the presence localities do not show statistically significant differences among species. July rainfall values only differ among $S$. variolosus and $S$. typhon. On the contrary, annual precipitation and minimum temperature in January seem to be the climatic variables with higher intra-species discrimination capacity (Table 2). However, the five species largely overlap in their inhabited climatic conditions (Fig. 8). S. variolosus seems to reach areas with a Mediterranean climate (low summer precipitation values) and with the highest winter temperatures. On the contrary, $S$. armeniacus seems to inhabit areas of higher altitude with the lowest winter and summer temperatures (Table 2 ). The remaining three species have very similar environmental requirements according to the distributional data analysed (Fig. 8).

\section{Discussion}

In Bulgaria, Scarabaeus species seem to be generally distributed across low altitude areas mainly under warm temperate or Mediterranean conditions. $S$. variolosus is the species adapted to the warmest conditions, being rare in the southernmost boundary of the country. S. armeniacus appears to prefer the opposite climatic spectrum, inhabiting the medium altitude areas of south-western Bulgaria. The distributions of the remaining species overlap greatly in terms of the climatic conditions of the analyzed presence data. This result can partially be a consequence of the limited studied area against the whole distributional area 
of the species; $S$. pius, $S$. sacer and $S$. typhon are the species with a wider distribution (around $4,800,7,500$ and $12,700 \mathrm{~km}^{2}$, respectively) compared with the more localised $S$. variolosus $\left(1,100 \mathrm{~km}^{2}\right)$ or $S$. armeniacus $\left(2,200 \mathrm{~km}^{2}\right)$. The three widely distributed species are also those that seem to have wider distributional areas in Bulgaria, occurring both in northern and in southern lowland territories.

In this paper we provide the classical dot maps, binary maps reflecting the most favourable localities (those below $10^{\text {th }}$ percentile) but also potential distribution representations in which a continuous suitability value was assigned to each grid cell. As the estimation of realized distributions inevitably require the use of reliable absence information (Lobo et al. 2010), the proportioned maps are just geographical representations dependent of the used resolution, the selected predictors and the available observed presences; potential distributions directed to reflect all the environmentally suitable places at which a species may occur according to the information provided by a group of climatic variables in observed occurrence localities. These so obtained potential distribution maps suggest that extra survey efforts should be carried out in the northern lowlands away from the Stara Planina Mts. in order to examine if these climatically suitable territories harbour new observations for some species. However, these areas near to the Danube lowlands have suffered considerable transformations in land use and Scarabaeus species seem to be especially sensitive to chemical contamination and habitat disturbance (Lobo 2001, Carpaneto \& Mazziota 2007). Recent exhaustive dung-beetle surveys (Lobo J.M., Guéorguiev, B. and Chehlarov, E., unpublished data) have only allowed us to collect two specimens of Scarabaeus pius in spite of a considerable sampling effort carried out in 77 localities distributed across the Bulgarian territory. Interestingly, this is the only Scarabaeus species for which a slight increase in the number of recorded specimens since 1970 can be observed (see Fig. 7). Based on year-long observations and fieldwork on Bulgarian dung beetles, Zacharieva-Stoilova $(1969,1974)$ already presented some time ago the existence of a "sensitive decrease" in the populations of Scarabaeus sacer, S. pius and S. typhon in Bulgaria. Accord- ing to this author, an increase in the extent of agricultural areas and changes in cattle breeding practices appear to be the main reasons leading to the decline of roller dung beetle populations. The current paper confirms that $S$. pius and S. typhon have been found in Bulgaria during the last four decades.

Acknowledgements. This paper was supported by a research project financed jointly by CSIC (Spain) and BAS (Bulgaria) (2005BG0022) and in part by the project "БMY-1101/01" financed by the Bulgarian Ministry of Education and Science. Special thanks to Conrad Gillett by his comments and revision of the text style.

\section{References}

Angelov, P. 1960 : Etudes sur l'entomofaune du parc “Délassement et culture" (l'ile au milieu de Maritsa) prčs de Plovdiv, avec quelques notes faunologiques. Godišnik na muzeite v Plovdiv 3: 7-40.

Angelov, P. 1965: Mistkäfer (Coprinae, Scarabaeidae) aus Bulgarien. - Travaux scientifique de l'ecole normale superieure, Plovdiv, Biologie, 3: 95-109.

Balthasar, V. 1963: Monographic der Scarabaeidae und Aphodiidae der Palaearktischen und Orientalischen Region (Coleoptera: Lamellicornia), 1 pp.391, PI. XXIV. - Verlag der Tschechoslowakischen Akademie der Wissenschaften. Prag.

Balthasar, V. \& Hrubant, M. 1960: Eine Beitrag zur Kenntniss der Scarabaeiden Albanien's. - Casopis Ceskoslovenske Spolecnosti Entomologicke. Praha 57: 146-153.

Barbero, E., Palestrini, C. \& Rolando, A. 1999: Dung beetle conservation: effects of habitat and resource selection (Coleoptera: Scarabaeoidea). — Journal of Insect Conservation 3: 75-84.

Basille, M., Calenge, C., Marboutin, E., Andersen, R. \& Gaillard, J. M. 2008: Assessing habitat selection using multivariate statistics: Some refinements of the ecological-niche factors analysis. - Ecological Modelling 211: 233-240.

Browne, D. J. \& Scholtz, C. H. 1995: Phylogeny of the families of the Scarabaeoidea (Coleoptera) based on characters of the hindwing articulation, hindwing base and wing venation. - Systematic Entomology 20: 145-173.

Browne, D. J. \& Scholtz, C. H. 1998: Evolution of the scarab hindwing articulation and wing base: a contribution toward the phylogeny of the Scarabaeidae (Scarabaeoidea: Coleoptera). — Systematic Entomology 23: 307-326.

Browne D. J. \& Scholtz, C. H. 1999: A phylogeny of the families of Scarabaeoidea (Coleoptera). - Systematic Entomology 24: 51-84.

Bunalski, M. 2000: Contribution to the knowledge Scara- 
baeoidea (Coleoptera) of Bulgaria. Part I. Results of the Expeditions 1996 and 1998. — Wiadomosti Entomologiczne 19: 85-92.

Byrne, M., Dacke, M., Nordström, P., Scholtz, C. \& Warrant, E. 2003: Visual cues used by ball-rolling beetles for orientation. - Journal of Comparative Physiology A: Neuroethology, Sensory, Neural, and Behavioral Physiology 189: 411-418.

Calenge, C. \& Basille, M. 2008: A general framework for the statistical exploration of the ecological niche. Journal of Theoretical Biology 252: 674-85.

Calenge, C., Darmon, G., Basille, M., Loison, A. \& Jullien, J. M. 2008: The factorial decomposition of the Mahalanobis distances in habitat selection studies. Ecology 89: 555-66.

Cambefort, Y. 1991: Biogeography and evolution — In: Hanski I. \&.Cambefort, Y. (eds.), Dung Beetle Ecology, Princeton University Press, New Jersey, pp. 5167.

Carpaneto, G. M. \& Mazziotta, A. 2007: Inferring species decline from collection records: roller dung beetles in Italy (Coleoptera Scarabaeidae). — Diversity and Distributions 13: 903-919.

Csiki, E. 1943: Coleopteren von Alibotusch-Gebirge in Süd-Bulgarien. - Mitteilungen aus den Königlichen Naturwissenschaftlischen Instituten, Sofia 16: 214 218

Davis, A. L. V., Scholtz, C. H \& Philips, T. K. 2002: Historical biogeography of Scarabaeine dung beetles. Journal of Biogeography 29: 1217-1256.

Davis, A. L. V., Scholtz, C. H., Dooley, P. W., Bham, N. \& Kryger, U. 2004: Scarabaeinae dung beetles as indicators of biodiversity, habitat transformation and pest control chemicals in agro-ecosystems. - South African Journal of Science 100: 415-424.

Dimitrova, E. \& Genov, T. 1966: New intermediate hosts of spirurates in pigs. - Comptes rendus de l'Académie bulgare des Sciences 19/12: 1215-1217.

Dimitrova E. \& Genov, T. 1968: Intermediary and reservoir hosts of Spirocerca lupi in Bulgaria. - Bulletin of the central helminthological laboratory 12: 79-85.

Drenski, P. 1942: Über die Insektenfauna des Küstengebietes nördlich von Warna. - Mitteilungen der Bulgarischen Entomologischen Gesellschaft in Sofia 12: 1544.

Farber, O. \& Kadmon, R. 2003: Assessment of alternative approaches for bioclimatic modelling with special emphasis on the Mahalanobis distance. - Ecological Modelling 160: 115-130.

Forgie, S. A, Philips, T. K \& Scholtz, C. H. 2005: Evolution of the Scarabaeini (Scarabaeidae: Scarabaeinae). — Systematic Entomology 30: 60-96.

Forgie, S. A., Kryger, U., Bloomer, P. \& Scholtz, C. H. 2006: Evolutionary relationships among the Scarabaeini (Coleoptera: Scarabaeidae) based on combined molecular and morphological data. - Molecular Phylogenetics and Evolution 40: 662-678.

Gittings, T. \& Giller, P. S. 1999: Larval dynamics in an assemblage of Aphodius dung beetles. - Pedobiologia 43: 439-452.
Gittings, T., Giller P. S. \& Stakelum, G. 1994: Dung decomposition in contrasting temperate pastures in relation to dung beetle and earthworm activity. - Pedobiologia 38: 455-474.

Guéorguiev, B. 2001: Beetles (Insecta: Coleoptera) in Kresna Gorge (SW Bulgaria). — In: Beron, P. (ed.), Biodiversity of the Kresna Gorge, pp. 163-188.

Halffter, G. \& Edmonds W. D. 1982: The nesting behavior of dung beetles (Scarabaeinae): an ecological and evolutive approach. - Instituto de Ecología, México Distrito Federal, México. 176 pp.

Hanski, I. \& Cambefort, Y. 1991. Dung Beetle Ecology. — Princeton University Press. Princeton, New Jersey. $481 \mathrm{pp}$.

Hijmans, R. J., Cameron, S. E., Parra J. L, Jones, P. G. \& Jarvis, A. 2005: Very high resolution interpolated climate surfaces for global land areas. - International Journal of Climatology 25: 1965-1978.

Hirzel, A. H., Hausser, J., Chessel, D. \& Perrin, N. 2002: Ecological-niche factor analysis: How to compute habitat - suitability maps without absence data? - Ecology 83: 2027-2036.

Hirzel, A. H., Hausser, J. \& Perrin, N. 2004: Biomapper 3.1. - Lab of Conservation Biology, Department of Ecology and Evolution, University of Lausanne. [www document]. URL: http://www.unil.ch/biomapper. (Site visited on March, 2009)

Hole, D. G., Perkins, A. J., Wilson, J. D., Alexander, I. H, Grice, P. V. \& Evans, A. D. 2005: Does organic farming benefit biodiversity? - Biological Conservation 122: 113-130.

Horgan, F. G. \& Berrow, S. D. 2004: Hooded crow foraging from dung pats: implications for the structure of dung beetle assemblages. Biology and Environment: - Proceedings of the Royal Irish Academy 104b: $119-124$.

Hutton, S. \& Giller, P. S. 2003: The effects of the intensification of agriculture on northern temperate dung beetle communities. - Journal of Applied Ecology 40: 994-1007.

Jiménez-Valverde, A., Lobo J. M. \&. Hortal, J. 2008: Not as good as they seem: the importance of concepts in species distribution modelling. - Diversity and Distribution 14: 885-890.

Joakimov, D. 1899: Contribution to the fauna of the insects of the Rila Mountain. - Periodichesko spisanie na bulgarskoto knizhovno druzhestvo v Sofia 59: 758 778.

Karnoschitzky, N. 1959: Materialien zur Koleopterenfauna der ägäischen Küste und Insel Thasos. - Bulletin de l'Institut zoologique de l'Academie des sciences de Bulgarie 8: 237-253.

Král, D. \& Malý, V. 1993: New records of Scarabaeoidea (Coleoptera) from Bulgaria. - Acta Societatis Zoologicae Bohemoslovacae 57: 17-29.

Leclerc J., Gaspar, C., Marchal, J. K., Verstraeten, C. \&. Wonville, C. 1980: Analyse des 1600 premičres cartes de l'Atlas provisoire des insectes de Belgique, et premičre liste rouge d'insectes menacés dans la faune belge. - Notes Fauniques de Gembloux 4: 1-104. 
Löbl, I., Krell, F. T. \&. Král, S. 2006: Scarabaeini, pp. 177178. — In: Löbl I. \& Smetana, A. (eds.), Catalogue of Palaearctic Coleoptera, Vol. 3. Stenstrup: Apollo Books, 690 pp.

Lobo, J. M. 2001: Decline of roller dung beetle (Scarabaeinae) populations in the Iberian Peninsula during the $20^{\text {th }}$ century. - Biological Conservation 97: 43-50.

Lobo, J. M., Sanmartin, I. \&. Martín-Piera, F. 1997: Diversity and spatial turnover of dung beetles (Col., Scarabaeoidea) communities in a protected area of south Europe (Doñana National Park, Huelva, Spain). Elytron 11: 71-88.

Lobo, J. M., Lumaret, J. P. \& Jay-Robert, P. 2001: Diversity, distinctiveness and conservation status of the Mediterranean coastal dung beetle assemblage in the Regional Natural Park of the Camargue (France). - Diversity and Distributions 7: 257-270.

Lobo, J. M., Jiménez-Valverde, A. \& Hortal, J. 2010: The uncertain nature of absences and their importance in species distribution modelling. - Ecography: 33: 103-114

Lumaret, J. P. 1990: Atlas des Coléoptčres Scarabeides Laparosticti de France. - Múseum National d'Histoire Naturelle, Inventaires de Faune et de Flore, fascicule 1; Secretariat de la Faune et de la Flore. Paris. 418 pp.

Lumaret, J. P. \&. Kirk, A. A 1991: South temperate dung beetles. - In: Hanski, I. \& Cambefort, Y. (eds.), Dung Beetle Ecology. Princeton University Press, Oxford, pp. 97-115.

Martín-Piera, F. \& Lobo, J. M. 1992: Los Scarabaeoidea Laparosticti del archipiélago Balear (Coleoptera). Nouvelle Revue Entomologie (N.S.) 9: 15-28.

Markovich, A. 1904: Matériaux de la faune entomologique dans les environs de Razgrade. - Travaux de la Societé bulgare des sciences naturelles 2: 220-252.

Markovich, A. 1909: Contribution to the fauna of insects of the vicinity of Razgrad. - Sbornik za narodni umotvorenia, nauka i knižnina 25: 1-20.

Mc Geoch, M. A., Van Rensburg, B. J. \& Botes, A. 2002: The verification and application of bioindicators: a case study of dung beetles in a savanna ecosystem. Journal of Applied Ecology 39: 661-672.

Mikšić, R. 1953: Fauna Insectorum Balcanica - Scarabaeidae. - Godišnjak Biološkog instituta u Sarajevu 6: 49-281.

Mikšić, R. 1955: Beitrag zur Kenntnis der Scarabaeidenfauna von Mazedonien (Coleoptera - Lamellicornia) (20. Beitrag zur Kenntnis der Scarabaeiden). — Acta Musei Macedonici scientiarum naturalium 3: 227246.

Mikšić, R. 1957: Zweiter Nachtrag zur "Fauna Insectorum Balcanica - Scarabaeidae”. (Coleoptera, Lamellicornia). (24. Beitrag zur Kentniss der Scarabaeidae). Acta Musei Macedonici scientiarum naturalium 4: 139-214

Mikšić, R. 1959: Dritter Nachtrag zur "Fauna Insectorum Balcanica - Scarabaeidae”. - Godišnjak Biološkog instituta u Sarajevu 12: 47-136.

Montreuil, O. 1998: Analyse phylogénétique et paraphylie des Coprini et Dichotomiini (Coleoptera: Scarabaeidae). Scénario biogéographique. - Annales de la Société Entomologique de France 34: 135-148.

Muche, W. H. 1964: Über die Lamellicornia, Alleculidae und Meloidae von Nessebar (Bulgarien) (Coleoptera). - Entomologische Abhandlungen und Berichte aus dem Staatlich Museum für Tierkunde in Dresden 32: 61-68.

Nedelkov, N. 1905: Contribution to the entomological fauna of Bulgaria. - Periodichesko spisanie na bulgarskoto knizhovno druzhestvo v Sofia 66: 404-439.

Nedelkov, N. 1909: Our entomological fauna. - Archiv na ministerstvoto na narodnoto prosveshtenie 1: 83 135.

Netolitzky, F. 1912: Eine Sammelreise nach Bulgarien. Koleopterologische Rundschau 1: 137-143; 156-163.

Panin, S. 1957: Coleoptera Familia Scarabaeidae. — Fauna Republicii Populare Romîne Insecta 10: 1-315.

Philips, T. K., Scholtz, C. H \& Ocampo, F. C. 2002: A phylogenetic analysis of the Eucraniini (Scarabaeidae: Scarabaeinae). - Insect Systematics and Evolution 33: 241-252.

Philips, T. K., Pretorius, R. \& Scholtz, C. H. 2004: A phylogenetic analysis of the dung beetles: (Scarabaeidae: Scarabaeinae): Unrolling an evolutionary history. Invertebrate Systematics 18: 1-36.

Pittioni, B. 1940: Die Arten der Unterfamilie Coprinae (Scarabaeidae, Coleoptera) in der Sammlung des Kgs. Naturh. Museum in Sofia. - Mitteilungen aus den Königlichen Naturwissenschaftlischen Instituten, Sofia 13: 211-238.

Romero-Samper, J. \& Lobo, J. M. 2006: Los coleópteros Escarabeidos telecópridos del Atlas Medio (Marruecos): influencia del tipo de hábitat, altitud y estacionalidad y relevancia en las comunidades coprófagas (Coleoptera, Scarabaeidae). - Boletín Sociedad Entomológica Aragonesa 39: 235-244.

Schoolmeesters, P. 2007: World Scarabaeidae database. — In: Species 2000 \& ITIS Catalogue of Life: 2006 AnnualChecklist. [www document] URL http://www. catalogueoflife.org/search.php, (Site visited on May, 2008)

Stolfa, E. 1938: Revisione delle specie papearctiche del sottogenere Scarabaeus s. str. - Atti del Museo civico di Storia naturale Trieste 13: 141-156.

Trifonov, T. 1966: Coprophagous beetles as intermediary hosts of Macracanthorhynchus hirudinaceus (Pallas, 1871). - Veterinary science 3: 1073-1078.

Verdú, J. R., Díaz, A. \& Galante, E. 2004: Thermoregulatory strategies in two closely related sympatric Scarabaeus species (Coleoptera: Scarabaeinae). - Physiological Entomology 29: 32-38

Villalba, S., Lobo, J. M. Martín-Piera, F. \& Zardoya, R. 2002: Phylogenetic relationships of Iberian dung beetles (Coleoptera: Scarabaeinae): Insights on the evolution of nesting behaviour. - Journal of Molecular Evolution 55: 116-126.

Zacharieva, B. 1965a: Beitrag zur untersuchung der koprophagen Scarabaeoidea (Coleoptera) aus dem 
Stranžagebirge. — Bulletin de l'Institut de Zoologie et Musée 18: 141-144.

Zacharieva, B. 1965b: Beitrag zur erforschung der coprophagen Scarabaeoidae (Coleoptera) aus den Ostrhodopen. - Bulletin de l'Institut de Zoologie et Musée 19: 129-134.

Zacharieva, B. 1965c: Scarabaeidae (Coleoptera) aus Thrakien. - In: Valkanov A. K. (ed.), Die Fauna Thrakiens. Sofia, 2: 229-254.

Zacharieva, B. \& Dimova, V. 1975: Fauniscthe untersuchungen über die Scarabaeidae (Coleoptera) aus den Rhodopen. - In: Peshev, G. (ed.), La faune des Rhodopes. Materiaux. Sofia. 183-196.

Zacharieva-Stoilova, B. 1969: Forschungen über Scarabaeidae (Coleoptera) im Westlichen "Stara-Planina"Gebirge. - Bulletin de l'Institut de Zoologie et Musée 30: 5-36.

Zacharieva-Stoilova, B. 1974: Scarabaeidae von dem mittleren und dem östlichen Balkangebirge. - Bulletin de l'Institut de Zoologie et Musée 41: 123-139.

Zaharieva, B., Dimova, V. \& Krusteva, V. 1975: Coprophilous Scarabaeidae (Coleoptera) from the Bulgarian Black Sea Coast. - Acta zoologica bulgarica 3: 3138.
Zaharieva-Stoilova, B. \& Dimova, V. 1980: Population ecology studies on coprophilous species of the family Scarabaeidae (Coleoptera) in a submediterranean type pasture ecosystem I. Dynamics of the number species. - Ecology 6: 16-25.

Zaharieva-Stoilova, B. \& Dimova, V. 1981: Coprophilous Beetles (Coleoptera, Scarabaeidae) from the Petrich Town Vicinity (Southwestern Bulgaria). - Acta zoologica bulgarica 18: 90-95.

Zunino, M. 1984 : Essai préliminaire sur l'évolution des armures génitales des Scarabaeinae, par rapport ŕ la taxonomie du groupe et ŕ l'évolution du comportement de nidification. - Bulletin de la Société Entomologique de France 88: 531-542.

Zunino, M. 1985: Las relaciones taxonómicas de los Phanaeina (Coleoptera, Scarabaeinae) y sus implicaciones biogeográficas. - Folia Entomológica Mexicana 64: 101-115.

Zur Strassen, R. 1967: Arten-übersicht der Gattung Scarabaeus Linnaeus (Scarabaeidae) mit besonderer Berücksichtigung der äthiopischen Formen. - Entomologisches Blätter 63 129-173. 
Appendix. Localities cited by countries and their geographic coordinates in latitude and longitude (decimals).

\begin{tabular}{|c|c|c|c|c|c|}
\hline Locality & Latitude & Longitude & Locality & Latitude & Longitude \\
\hline Albania & & & Hrabrino & 42.05 & 24.65 \\
\hline Berat & 40.70 & 19.93 & Kamchia River (outfall) & 43.03 & 27.88 \\
\hline Dukati & 40.33 & 19.43 & Kalimantsi & 41.47 & 23.48 \\
\hline Durres & 41.32 & 19.43 & Kamenitsa near Strumyani & 41.65 & 23.17 \\
\hline Kanine & 40.44 & 19.52 & Kamilski Dol near Ivailovgrad & 41.53 & 26.13 \\
\hline Liquen i Butrintit & 39.78 & 20.03 & Kardzhali & 41.65 & 25.37 \\
\hline Llogora & 40.20 & 19.58 & Karnobat & 42.65 & 26.98 \\
\hline Maj'e Kjores (= Kjores Mt.) & 40.22 & 19.62 & Kazanlak & 42.62 & 25.40 \\
\hline Oroshi & 41.83 & 20.08 & Kozhuh Hill & 41.43 & 23.25 \\
\hline \multirow[t]{2}{*}{ Vlorë (= Valona) } & 40.47 & 19.49 & Kresna (= Gara Pirin) & 41.77 & 23.23 \\
\hline & & & Kresna Gorge & 41.80 & 23.17 \\
\hline Bosnia Herzegovina & & & Krichim & 42.05 & 24.47 \\
\hline Bileće & 42.87 & 18.43 & Krumovgrad & 41.47 & 25.65 \\
\hline Domanovići & 43.14 & 17.78 & Kyustendil & 42.28 & 22.68 \\
\hline Donje Hrasno & 42.99 & 17.76 & Lebnitsa (Ograzhden Mt.) & 41.53 & 23.23 \\
\hline Hutovo Blato (= Utovo Blato) & 43.06 & 17.79 & Lilyanovo & 41.62 & 23.32 \\
\hline Klobuk & 43.28 & 17.45 & Lom & 43.83 & 23.25 \\
\hline Ljubinje & 42.95 & 18.09 & Lyulin Mt. & 42.67 & 23.08 \\
\hline Mostar & 43.34 & 17.81 & Malko Tarnovo & 41.98 & 27.53 \\
\hline Mostarsko Blato & 43.33 & 17.69 & Mandritsa & 41.38 & 26.13 \\
\hline Neum & 42.95 & 17.73 & Marino Pole near Petrich & 41.42 & 23.35 \\
\hline Podvelež & 43.29 & 17.92 & Meden Buk & 41.37 & 26.03 \\
\hline Stolac & 43.08 & 17.88 & Meden Rudnik (= Karabair) & 42.45 & 27.40 \\
\hline Trebinje & 42.73 & 18.31 & Melnik & 41.52 & 23.40 \\
\hline \multirow[t]{2}{*}{ Velež Mt. } & 43.87 & 17.68 & Mitino & 41.43 & 23.25 \\
\hline & & & Muldava & 41.98 & 24.95 \\
\hline Bulgaria & & & Nesebar (= Mesemvria) & 42.65 & 27.73 \\
\hline Arkutino & 42.33 & 27.73 & Novi Iskar (= Kurilo) & 42.82 & 23.35 \\
\hline Asenovgrad (= Stanimaka) & 42.02 & 24.97 & Ognyanovo near Pazardzhik & 42.15 & 24.42 \\
\hline Bachkovski Monastery & 41.93 & 24.85 & Orlitsa & 41.32 & 25.40 \\
\hline Belasitsa Mt. & 41.37 & 23.13 & Ostrova Place near Plovdiv & 42.15 & 24.70 \\
\hline Belila near Grudovo & 42.33 & 27.10 & Parvenets (= Ferdinandovo) & 42.07 & 24.67 \\
\hline Beloslav & 43.20 & 27.73 & Pazardzhik & 42.20 & 24.33 \\
\hline Blagoevgrad (? Parangalitsa) & 42.02 & 23.10 & Perushtitsa & 42.07 & 24.55 \\
\hline Bornarevo (= Bomarevo) & & & Peshtera & 42.03 & 24.30 \\
\hline near Radomir & 42.53 & 22.93 & Petrich & 41.40 & 23.22 \\
\hline Bratsigovo & 42.02 & 24.37 & Petrich ("Sv. Vargoo" Place) & 41.45 & 23.17 \\
\hline Burgas & 42.50 & 27.47 & Petrovo & 41.43 & 23.52 \\
\hline Dolna Dikanya & 42.43 & 23.12 & Plovdiv & 42.15 & 24.75 \\
\hline Dragoman & 42.92 & 22.93 & Podkova & 41.40 & 25.40 \\
\hline Drangovo & 41.42 & 23.28 & Primorsko (= Kyupria; & & \\
\hline Dulovo & 43.82 & 27.08 & Stamopolu) & 42.25 & 27.63 \\
\hline Dupnitsa & 42.28 & 23.15 & Radomir env. (Golo Bardo Mt.) & 42.47 & 23.02 \\
\hline Evksinograd near Varna & 43.15 & 28.00 & Ravna Gora (Strandzha Mt.) & 42.37 & 27.55 \\
\hline Gara Krichim & 42.13 & 24.53 & Razgrad & 43.53 & 26.52 \\
\hline Gara Razgrad & 43.57 & 26.50 & Rezovo & 41.99 & 28.03 \\
\hline Golo Bardo Mt. & 42.55 & 23.07 & Rila Mt. & 42.13 & 23.55 \\
\hline Gorna Breznitsa (N of) & 41.77 & 23.09 & Rilski Monastery & 42.13 & 23.33 \\
\hline Gorna Breznitsa (W of) & 41.75 & 23.12 & Ropotamo River's outfall & 42.33 & 27.77 \\
\hline Gradishte (Golo Bardo Mt.) & 42.55 & 23.07 & Sadovo & 42.13 & 24.93 \\
\hline Harmanli & 41.93 & 25.90 & Samokov & 42.33 & 23.55 \\
\hline Hisar & 42.50 & 24.70 & Sestrimo near Pazardzhik & 42.22 & 23.92 \\
\hline
\end{tabular}




\begin{tabular}{|c|c|c|c|c|c|}
\hline Locality & Latitude & Longitude & Locality & Latitude & Longitude \\
\hline Shtit (= Yuskudar) & & & Greece & & \\
\hline near Svilengrad & 41.83 & 26.36 & Amphissa & 38.40 & 22.45 \\
\hline Simeonovgrad & 42.05 & 25.88 & Askifou (Lefka Ori, & & \\
\hline Simitli & 41.88 & 23.17 & Crete Island) & 35.28 & 24.18 \\
\hline Slavyanka Mt. & 41.38 & 23.60 & Asteri nead Skala & & \\
\hline Sliven & 42.69 & 26.33 & (Elos District) & 36.50 & 22.43 \\
\hline Sredets (= Grudovo) & 42.35 & 27.19 & Athens & 37.98 & 23.73 \\
\hline Stara Kresna & 41.80 & 23.18 & Chalkis (Euboea Island) & 38.46 & 23.60 \\
\hline Stara Zagora & 42.43 & 25.64 & Chamkjoiski Monastery & & \\
\hline Strandzha Mt. & 42.07 & 27.00 & near Soufli & 41.19 & 26.30 \\
\hline Tsarevo & 42.10 & 27.82 & Chani Driskos near Janina & 39.67 & 20.85 \\
\hline Turia & 42.57 & 25.18 & Crete Island & 35.25 & 24.75 \\
\hline Varna & 43.22 & 27.92 & Delphi & 38.63 & 23.83 \\
\hline Varna ( $\mathrm{N}$ of) & 43.23 & 28.02 & Eleftera Monastery & & \\
\hline Venets near Burgas & 42.63 & 26.80 & near Kavala & 40.91 & 24.25 \\
\hline Vidin & 43.99 & 22.87 & Hortiatis Mt. & 40.58 & 23.12 \\
\hline Vitosha Mt. & 42.55 & 23.25 & Kavala & 40.94 & 24.40 \\
\hline Vulkovo (W of) & 41.58 & 23.22 & Kiphissia & 38.07 & 23.82 \\
\hline \multirow[t]{2}{*}{ Zvezditsa near Varna } & 43.15 & 27.85 & Korfu Island & 39.67 & 19.75 \\
\hline & & & Lianikladia near Kamia & 38.54 & 22.26 \\
\hline Croatia & & & Limenaria (Thasos Island) & 40.63 & 24.58 \\
\hline Babin Dub & 44.09 & 15.32 & Megaspilaon & 38.50 & 22.10 \\
\hline Bakar & 45.31 & 14.53 & Nauplia & 37.56 & 22.81 \\
\hline Baška Nova (Krk Island) & 44.97 & 14.75 & Naxos Island & 37.11 & 25.38 \\
\hline Biokovo Mt. & 43.33 & 17.05 & Okchilar near Xanthi & 41.08 & 24.80 \\
\hline Bokanjac & 44.15 & 15.25 & Ossa Mt. & 39.75 & 22.58 \\
\hline Cres & 44.96 & 14.41 & Parnass Mt. & 38.53 & 22.62 \\
\hline Crikvenica & 45.17 & 14.70 & Pelion Monastery & 36.17 & 28.00 \\
\hline Dubrovnik & 42.65 & 18.09 & Phaleron & 37.93 & 23.70 \\
\hline Dugi Otok & 43.98 & 15.07 & Rhodos Island & 36.17 & 28.00 \\
\hline Grižane & 45.20 & 14.72 & Soufli & 41.19 & 26.30 \\
\hline Grobnik & 45.23 & 14.10 & Stylis & 38.92 & 22.62 \\
\hline Knin & 44.04 & 16.20 & Syra Island & 37.45 & 24.93 \\
\hline Kraljevica & 45.27 & 14.57 & Theologos (Thasos Island) & 40.67 & 24.70 \\
\hline Krasica & 45.31 & 14.56 & Tripolis & 37.51 & 22.38 \\
\hline Lakmartin & 45.05 & 14.59 & Velestino & 39.38 & 22.75 \\
\hline Meja & 45.29 & 14.59 & Velouchi Mt. & 38.56 & 21.48 \\
\hline Metkovic & 43.05 & 17.65 & Volo & 39.37 & 22.95 \\
\hline Nadimsko Blato & 44.03 & 15.48 & Xanthi & 41.14 & 24.88 \\
\hline Novi Vinodolski & 45.13 & 14.79 & Zachlorou & 38.50 & 22.90 \\
\hline Obrovac & 44.20 & 15.68 & Zante & 37.75 & 20.75 \\
\hline Rijeka & 45.34 & 14.41 & Kosovo & & \\
\hline Senj & 42.63 & 18.70 & Gračanica & 42.60 & 21.20 \\
\hline Split & 43.38 & 16.60 & Macedonia & & \\
\hline Starigrad (Hvar Island) & 43.18 & 16.60 & Bitolya env. & 41.03 & 21.34 \\
\hline Trogir & 43.53 & 16.17 & Gara Pcinja & 41.82 & 21.67 \\
\hline Vinodol & 45.22 & 14.70 & Gevgelja & 41.20 & 22.40 \\
\hline Visoko & 46.09 & 16.33 & Prilep & 41.33 & 21.58 \\
\hline \multirow[t]{2}{*}{ Vrgorac-Propotnica } & 43.20 & 17.37 & Stari Dojran & 41.19 & 22.72 \\
\hline & & & Vodoca & 41.45 & 22.59 \\
\hline European Turkey & & & Zelenikovo & 41.89 & 21.59 \\
\hline Kuru Dagh Mt. & 40.70 & 26.75 & & & \\
\hline \multirow[t]{2}{*}{ Merefte } & 40.67 & 27.25 & Montenegro & & \\
\hline & & & Koto & 42.43 & 18.77 \\
\hline
\end{tabular}




\begin{tabular}{|c|c|c|c|c|c|}
\hline Locality & Latitude & Longitude & Locality & Latitude & Longitude \\
\hline Krasići & 42.41 & 18.64 & Tecuci & 45.87 & 27.42 \\
\hline Sutorman & 42.16 & 19.10 & Tulcea & 45.17 & 28.80 \\
\hline Titograd & 42.44 & 19.26 & Turno-Severin & 44.63 & 22.66 \\
\hline Virpazar & 42.25 & 19.09 & Vasile-Roaita & 44.55 & 27.70 \\
\hline Romania & & & Serbia & & \\
\hline Agigea & 44.08 & 28.62 & Bela Palanka & 43.22 & 22.33 \\
\hline Branesti & 45.82 & 28.08 & Dimitrovgrad (= Tsaribrod) & 43.01 & 22.78 \\
\hline Bucharest & 44.50 & 26.08 & Grebenac (Vojvodina Region) & 44.90 & 21.23 \\
\hline Calafat & 43.99 & 22.93 & Horgos near Grebenac & & \\
\hline Calarashi & 44.25 & 27.00 & (Vojvodina) & 46.16 & 19.97 \\
\hline Cardon & 45.23 & 29.63 & Mramorak (Vojvodina) & 44.90 & 21.08 \\
\hline Constantsa & 44.25 & 28.33 & Palić (Vojvodina) & 46.11 & 19.77 \\
\hline Hirshova & 44.68 & 27.93 & Pozharevats & 44.61 & 21.17 \\
\hline Istria & 44.57 & 28.72 & Ram & 44.81 & 21.33 \\
\hline Jana Mare & 44.41 & 22.69 & Sušara (Vojvodina) & 44.94 & 21.13 \\
\hline Letea & 45.30 & 29.52 & Usje & 44.68 & 21.60 \\
\hline Sadova & 43.90 & 23.95 & Vince & 44.71 & 21.61 \\
\hline Techirghiol & 44.05 & 28.60 & Zatonje near Veliko Gradiste & 44.76 & 21.38 \\
\hline
\end{tabular}

